\title{
Determinanty prawne ustalania wielkości obszaru objętego decyzją o warunkach zabudowy i miejscowych planów zagospodarowania przestrzennego
}

\section{Wprowadzenie}

Decyzja o warunkach zabudowy i zagospodarowaniu terenu, która zgodnie z Ustawą z dnia 27 marca 2003 r. o planowaniu i zagospodarowaniu przestrzennym ${ }^{1}$ może przyjacć postać decyzji o lokalizacji inwestycji celu publicznego lub decyzji o warunkach zabudowy, to instytucja dobrze znana w polskim systemie prawnym, gdyż dotychczas to właśnie ona była najczęściej podstawą rozpoczęcia żmudnego procesu realizacji wielu inwestycji. Stan taki wynika wprost z braku obowiązywania wystarczającej liczby miejscowych planów zagospodarowania przestrzennego (dalej „m.p.z.p."). Mimo że obecnie liczba miejscowych planów stale wzrasta, to jednak objęcie nimi w pełni obszarów, dla których istnieje uzasadniona potrzeba ich sporządzenia, to ciągle odległa przyszłość. Stąd decyzje o warunkach zabudowy i zagospodarowania terenu, w szczególności decyzje o warunkach zabudowy, stanowią i będą stanowić istotny element uzyskiwania informacji o sposobie zagospodarowania i zabudowy określonych terenów. Jednocześnie w literaturze przedmiotu istnieje wiele opracowań przedstawiających charakter prawny decyzji o warunkach zabudowy ${ }^{2}$. Zasadniczo w kwestiach

1 Tekst jedn. Dz.U. 2016, poz. 778 ze zm., dalej „u.p.z.p.”.

${ }^{2}$ Zob.: Z. Czarnik, Treść $i$ charakter prawny decyzji ustalającej warunki zabudowy $i$ zagospodarowania terenu, "Samorząd Terytorialny” 1999, nr 10 s. 60 i n.; D. Włodarczyk, Z problematyki teoretyczno-prawnej decyzji o warunkach zabudowy i zagospodarowania terenu, 
podstawowych znakomita większość z nich zgadza się i uznaje, że jest to szczególny rodzaj decyzji administracyjnej, będącej aktem indywidualnym i konkretnym, co do zasady deklaratoryjnym, związanym, a także osobowym. Zdecydowanie rzadziej spotyka się pogłębioną analizę na temat jej poszczególnych elementów, które zdają sie wymykać standardowym kwalifikacjom ${ }^{3}$. Wynika to przede wszystkim ze stosowania klasycznych kryteriów wyróżniania poszczególnych form prawnych działania administracji publicznej, które nie oddają całej jej złożoności.

Niniejsze opracowanie jest odpowiedzią na pytanie, jak wielki obszar może objąć pojedyncza decyzja o warunkach zabudowy, co związane jest $\mathrm{z}$ kwestią zakresu traktowania jej jako narzędzia zastępczego dla miejscowego planu zagospodarowania przestrzennego. Zdarza się bowiem tak, że realizacja zamierzenia inwestycyjnego obejmującego kilka obiektów budowlanych, a niekiedy całe osiedla, przy braku miejscowych planów niejednokrotnie następuje na podstawie decyzji administracyjnej, a nie aktu prawa miejscowego. Mimo że praktyka podpowiada, iż takie kompleksowe akty administracyjne funkcjonują w obrocie prawnym, a ich ewentualne skuteczne wzruszenie jako aktów ostatecznych naruszałoby prawa nabyte, co zapewne wymagałoby niemałych odszkodowań, to interesujące i aktualne pozostaje pytanie, czy istnieją prawne determinanty obszaru, którymi należy objać miejscowy plan i decyzję o warunkach zabudowy. Bezpośrednią inspiracją do zajęcia się wskazaną problematyką są niektóre sposoby zagospodarowywania przestrzeni miasta Poznania. $Z$ jednej strony uchwala się bowiem miejscowy plan dla niewielkich powierzchni, np. dla $188 \mathrm{~m}$ kw. ${ }^{4}, \mathrm{z}$ drugiej strony dla terenów wielkości jednego hektara prowadzi

\footnotetext{
"Studia Prawno-Ekonomiczne" 1997, t. 56; K. Świderski, Charakter prawny decyzji o warunkach zabudowy i zagospodarowania terenu, "Radca Prawny" 2001, nr 1; T.B. Babiel, Pozwolenie budowlane, Warszawa 2000, s. 6-7; T. Bąkowski, Decyzja o warunkach zabudowy i zagospodarowania terenu, Warszawa 2001, s. 185; Z. Niewiadomski, Planowanie przestrzenne w systemie zadań samorzadu terytorialnego. Zagadnienia administracyjnoprawne, Warszawa 1994; K. Jaroszyński, M. Sawicki, Decyzje o warunkach zabudowy i zagospodarowania terenu w świetle ustawy o planowaniu i zagospodarowaniu przestrzennym. Poradnik, Warszawa 2004; J. Goździewicz-Biechońska, Decyzja o warunkach zabudowy i zagospodarowania terenu, „Państwo i Prawo” 2002, z. 2, s. 95-108; Z. Leoński, M. Szewczyk, M. Kruś, Prawo zagospodarowania przestrzeni, Warszawa 2012.

${ }^{3}$ Zob. Z. Leoński, M. Szewczyk, M. Kruś, op. cit., s. 192 i n.

${ }^{4}$ Uchwała nr LVI/862/VI/2013 Rady Miasta Poznania z dnia 24 IX 2013 r. w sprawie miejscowego planu zagospodarowania przestrzennego „U zbiegu placu Wiosny Ludów i ulicy Podgórnej" w Poznaniu (http://www.mpu.pl/plany.php?s=6\&p=222, dostęp: 16 IV 2014); zob. też uchwała nr LXXX/1203/V/2010 Rady Miasta Poznania z dnia
} 
się postępowanie w sprawie wydania decyzji o warunkach zabudowy. Mimo że takie działania organów planistycznych nie są wprost zakazane i brak też ograniczeń co do obszaru, który mogą objać, to jednak ciekawe wydaje się zagadnienie ich właściwego określenia.

\section{Decyzja o warunkach zabudowy a miejscowy plan zagospodarowania przestrzennego}

Zasadnicza część odpowiedzi na pytanie, czy decyzja o warunkach zabudowy w skrajnym wypadku może zawsze zastąpić miejscowy plan, wymaga uprzedniego wyraźnego wskazania istotnych cech obu form prawnych działania administracji publicznej. Odnalezienie essentialia negotii każdej z nich oraz nieprzekraczalnych różnic będzie dowodziło ich odmienności i braku automatycznej zastępowalności. Z pozoru sprawa nie wydaje się zatem aż tak skomplikowana, gdyż już sama Ustawa z dnia 27 marca 2003 r. o planowaniu i zagospodarowaniu przestrzennym oraz bogata literatura przedmiotu ${ }^{5}$ wskazuje wiele argumentów przemawiających za odmiennym ich traktowaniem.

Po pierwsze, nie ma wątpliwości, że decyzja o warunkach zabudowy jest aktem administracyjnym indywidualnym, natomiast miejscowy plan jest aktem normatywnym, aktem prawa miejscowego w znaczeniu formalnym, o czym przesądza sam ustawodawca w art. 14 ust. 8 u.p.z.p. To pierwsze rozróżnienie doprowadza do jakże interesujących wniosków. Mianowicie art. 4 ust. 2 u.p.z.p. stanowi wprost, że w przypadku braku miejscowego planu zagospodarowania przestrzennego określenie sposobów zagospodarowania i warunków zabudowy terenu następuje $\mathrm{w}$ drodze decyzji o warunkach zabudowy i zagospodarowania terenu. Tym samym co do zasady przepis prawa powszechnie obowiązującego jest zastępowany aktem administracyjnym indywidualnym. To rozwiązanie może nawet budzić wątpliwości w kwestii zgodność z Konstytucją

9 XI 2010 r. w sprawie miejscowego planu zagospodarowania przestrzennego "U zbiegu ulic Szkolnej i Paderewskiego" w Poznaniu (http://www.mpu.pl/plany.php?s=6\&p=207, dostęp: 16 IV 2014).

${ }^{5}$ Zob. w szczególności: Z. Niewiadomski, Nowe prawo o planowaniu i zagospodarowaniu przestrzennym: podstawowe rozwiąania, tekst ustawy, teksty aktów wykonawczych (komentarz), Warszawa 2003; Z. Niewiadomski, K. Jaroszyński, Ustawa o planowaniu i zagospodarowaniu przestrzennym: komentarz, Warszawa 2009, zwł. przypis 1 i podana tam literatura. 
Rzeczypospolitej ${ }^{6}$, gdyż jednym z ważniejszych osiągnięć obowiązującej ustawy zasadniczej jest określenie zamkniętego katalogu źródeł prawa powszechnie obowiązującego. Stąd też zastępowanie wskazanego w art. 87 ust. 2 Konstytucji źródła prawa decyzją administracyjną w rozumienia Kodeksu postępowania administracyjnego stanowi istotne odstępstwo od ustalonego standardu i taką sytuację należy uznać za wyjątkową. Co więcej, w doktrynie i orzecznictwie pojawiają się głosy, że akty prawa miejscowego mają taką samą rangę jak rozporządzenia, gdyż oba akty wydawane są na podstawie delegacji ustawowej. Mimo że powyższa teza nie jest tak jednoznacznie akceptowalna, to jednak wskazuje na pozycję aktów prawa miejscowego w systemie źródeł prawa RP. Pamiętać jednak należy, że akty prawa miejscowego w systemie ładu przestrzennego są co do zasady wydawane fakultatywnie. Tym samym brak objęcia danego terenu planem mógłby skutkować uniemożliwieniem realizacji jednego z podstawowych praw konstytucyjnych i praw człowieka, tj. prawa własności. Ryzyko takiego niedozwolonego ograniczenia wyeliminowano częściowo właśnie poprzez instytucję decyzji o warunkach zabudowy, choć w przypadku braku spełnienia przesłanki z art. 61 ust. 1 pkt 1 u.p.z.p., tzw. „zasady dobrego sąsiedztwa”, inwestycje niemające charakteru publicznego i tak nie będą mogły być zrealizowane. Istotna pozostaje jednak kwestia, czy wydawanie decyzji administracyjnej zamiast aktu prawa miejscowego oznacza pełną zastępowalność aktu normatywnego.

Z faktu, że decyzja jest aktem administracyjnym, można wywodzić, iż w modelowym ujęciu powinna być aktem indywidualnym i konkretnym $^{8}$. Sposób określenia adresata nie budzi w jej przypadku wątpliwości, bowiem jest on wskazywany z imienia i nazwiska; podobnie też zachowanie wydaje się ustalone konkretnie. Z kolei konkretność tego rozstrzygnięcia wynika przede wszystkim z obowiązku dołączenia do wniosku informacji wskazanych w art. $52 \mathrm{w}$ zw. z art. 64 ust. 1 u.p.z.p. Tym samym przedmiotem wniosku nie może być ogólne zapytanie o dopuszczalne inwestycje na określonym terenie, ale to, czy konkretny obiekt budowlany może zostać w przyszłości zrealizowany. Stąd też

${ }^{6}$ Konstytucja Rzeczypospolitej Polskiej z dnia 2 IV 1997 r. (Dz.U. Nr 78, poz. 483 ze zm.), dalej „Konstytucja RP”.

${ }^{7}$ Zob. wyrok Naczelnego Sądu Administracyjnego (NSA) z 29 XII 2011 r., sygn. II GSK 183/12, LEX nr 1151248.

${ }^{8}$ Zob. K. Ziemski, Indywidualny akt administracyjny jako forma prawna działania administracji publicznej, Poznań 2005. 
decyzja taka, jak podkreśla M. Szewczyk, rozstrzyga o legalności lub nielegalności konkretnej inwestycji w określonym miejscu ${ }^{9}$. Nie wpływa na to fakt, że przy sporządzeniu wniosku brak jest obowiązku fachowości, a przedstawiona charakterystyka obiektu w formie opisowej i graficznej nie podlega tym samym regułom co sporządzenie obiektu budowlanego. Stąd też co do zasady uznaje się, że decyzja o warunkach zabudowy jest aktem indywidualnym i konkretnym ${ }^{10}$. Pewien element nieoznaczoności zawierają natomiast zagadnienia temporalne. Mianowicie decyzja ta obowiązuje w czasie w sposób potencjalnie niemalże nieograniczony, gdyż jest ważna dopóty, dopóki nie zostanie dla tego samego terenu uchwalony miejscowy plan, a zatem ta okoliczność nie jest wskazana konkretnie. Analizując istotę aktów indywidualnych i konkretnych z zakresu procesów inwestycyjnych, można jednak stwierdzić, że nawet pozwolenie na budowę, chociaż dotyczy określonego z imienia i nazwiska adresata oraz sporządzonego przez architekta-projektanta konkretnego obiektu budowlanego, nie wskazuje dokładnie, kiedy budowa musi być rozpoczęta oraz zakończona.

Z kolei miejscowy plan, mimo że, jak wskazuje praktyka, może dotyczyć tylko jednej, konkretnej nieruchomości, pozostaje w modelowym ujęciu ciągle aktem generalnym i abstrakcyjnym. Dowodzi tego zarówno sposób wskazania adresata (jest nim każdy, kto będzie w przyszłości np. wznosił obiekt budowlany czy też w inny sposób korzystał z objętych nim przestrzeni), jak i brak, w przypadku obiektów budowlanych, ostatecznego określenia ich parametrów technicznych. Ustala się w nim m.in. przeznaczenie terenu, parametry i wskaźniki kształtowania zabudowy i zagospodarowania terenu oraz rozmieszczenie inwestycji celu publicznego. W doktrynie zauważa się jednak ich szczególny charakter. Mianowicie z jednej strony Z. Niewiadomski twierdzi, że chociaż ustalenia planu miejscowego odnoszą się do abstrakcyjnego adresata, to regulują status konkretnych nieruchomości położonych na obszarze planu ${ }^{11}$. Sytuacja ta jest tym bardziej zauważalna, jeśli miejscowy plan obejmuje obszar tylko jednej, niepodzielonej nieruchomości, będącej pojedynczą działką gruntu. Z drugiej strony M. Szewczyk dowodzi

${ }^{9}$ Z. Leoński, M. Szewczyk, M. Kruś, op. cit., s. 83.

${ }^{10}$ Zob. T. Bąkowski, Komentarz do art. 4 ustawy o planowaniu i zagospodarowaniu przestrzennym, w: idem, Ustawa o planowaniu i zagospodarowaniu przestrzennym. Komentarz, Zakamycze 2004.

${ }^{11}$ Ustawa o planowaniu i zagospodarowaniu przestrzennym. Komentarz, pod red. Z. Niewiadomskiego, Warszawa 2006, s. 140, nb. 8. 
o w pełni normatywnym charakterze planu miejscowego, gdyż do istoty tego aktu należy określenie przeznaczenia terenu. Autor ten podkreśla, że miejscowy plan nie dotyczy żadnych konkretnych nieruchomości, lecz obowiązuje w obszarze o ściśle określonych granicach, a objęte nim nieruchomości mogą ulegać podziałom i łączeniu, co pozostanie bez wpływu na moc obowiązującą planu ${ }^{12}$. Tym samym tenże akt prawa miejscowego będzie aktem normatywnym w znaczeniu zarówno formalnym, jak i materialnym. Niewątpliwie abstrakcyjny charakter planu potwierdzają te jego postanowienia, które dotyczą zasad i warunków zagospodarowania, np.: ochrony środowiska, dziedzictwa kulturowego czy ochrony i kształtowania ładu przestrzennego i innych ${ }^{13}$. Jak podkreśla M. Szewczyk, zasady takie można kształtować w oderwaniu od konkretnego stanu faktycznego, bez konieczności dokonywania subsumcji ${ }^{14}$. Nie można jednak w oderwaniu od konkretnych uwarunkowań określić linii rozgraniczających tereny o różnym przeznaczeniu lub różnych zasadach zagospodarowania, granic zagospodarowania terenów lub obiektów podlegających ochronie czy terenów przeznaczonych na cele publiczne, w tym podlegające wywłaszczeniu. W tym wypadku miejscowy plan jest aktem prawa miejscowego tylko w znaczeniu formalnym, gdyż określenie wskazanych powyżej elementów wymaga ustalenia stanu faktycznego i przeprowadzenia postępowania dowodowego.

Powyższe rozważania doprowadzają do wniosku, że odróżnienie decyzji o warunkach zabudowy od miejscowego planu poprzez odwołanie się do instytucji aktów administracyjnych indywidualnych i normatywnych (generalnych ${ }^{15}$ ) co do zasady nie napotyka większych trudności. Wynika to przede wszystkim z tego, że decyzja o warunkach zabudowy jest aktem indywidualnym co do sposobu wskazania adresata i konkretnym co do okoliczności i wymaganego zachowania. Interesujące jednak jest to, że w swej drugiej części, w zakresie, w jakim potwierdza parametry konkretnego obiektu budowlanego czy stopień zabudowy działki gruntu, bliska jest miejscowemu planowi. W tym miejscu pojawia się zatem jedna z zasadniczych kwestii analizowanych w niniejszym opracowaniu, mianowicie, czy można dla takiego samego terenu wydać alternatywnie decyzję o warunkach zabudowy lub

${ }^{12}$ Z. Leoński, M. Szewczyk, M. Kruś, op. cit., s. 83.

${ }^{13}$ Zob. art. 15 ust. 2 pkt 8-10 u.p.z.p.

${ }^{14}$ Z. Leoński, M. Szewczyk, M. Kruś, op. cit., s. 119.

${ }^{15}$ Inne rozumienie aktu generalnego prezentują E. Szewczyk, M. Szewczyk w pracy Generalny akt administracyjny, Warszawa 2014, s. 91 i n. 
uchwalić miejscowy plan. Z formalnego punktu widzenia odpowiedź na to pytanie może być twierdząca pod warunkiem, że przedmiotem rozstrzygnięcia jest pojedyncza działka gruntu. Co prawda, zgodnie z zasadą dyspozycyjności, możliwość wydania decyzji przez organ ogranicza wniosek strony (art. 52 u.p.z.p.), ale pytanie to staje się już aktualne, jeśli wniosek taki został już złożony. Zaznaczyć należy, że nie chodzi w tym miejscu o możliwość zawieszenia postępowania w sprawie wydania decyzji o warunkach zabudowy i zagospodarowania terenu, jeśli wszczęto procedurę uchwalania planu.

Niezależnie od powyższego ustawa o planowaniu i zagospodarowaniu przestrzennym wskazuje wprost na istotny element różniący oba akty planowania przestrzeni. Mianowicie art. 4 ust. 1 u.p.z.p. stanowi, że miejscowy plan oprócz sposobu zagospodarowania i warunków zabudowy określa także przeznaczenie terenu. Autor celowo pomija możliwość rozmieszczenia $\mathrm{w}$ nim inwestycji celu publicznego, gdyż w ich przypadku może subsydiarnie zostać wydana odrębna decyzja administracyjna. Tym samym wyłącznie dla aktu prawa miejscowego zastrzeżono możliwość zmiany przeznaczenia terenów i właśnie ta różnica wskazywana jest jako podstawowa, a samemu planowi miejscowemu nadaje się status aktu konstytutywnego. Charakteru takiego nie ma natomiast $\mathrm{w}$ opinii większości doktryny decyzja o warunkach zabudowy. W orzecznictwie Trybunału Konstytucyjnego (TK) dominuje pogląd, zgodnie z którym decyzja o warunkach zabudowy nie ma charakteru decyzji konstytutywnej, nie tworzy stanu prawnego ani nie jest substytutem planu miejscowego $\mathrm{w}$ aspekcie merytorycznym i proceduralnym i stanowi jedynie szczegółową urzędową informację o tym, jaki obiekt i pod jakimi warunkami inwestor może na danym terenie wybudować bez obrazy przepisów prawa ${ }^{16}$. Wskazać jednak należy, że w rozpatrywanych sprawach skupiono się na pojęciu „obszar analizowany", zawartym w Rozporządzeniu Ministra Infrastruktury z dnia 26 sierpnia 2003 r. w sprawie sposobu ustalania wymagań dotyczących nowej zabudowy i zagospodarowania terenu w przypadku braku miejscowego planu zagospodarowania przestrzennego ${ }^{17} \mathrm{~W}$ aspekcie przekroczenia delegacji ustawowej przez ministra poprzez wprowadzanie nowego, materialnego przepisu, definicji "obszaru analizowanego", a nie na zagadnieniu "przeznaczenie terenu”. Niemniej szczegółowa analiza art. 61

${ }^{16}$ Zob. wyrok TK z 20 XII 2007 r., sygn. P 37/06, OTK-A 2007, nr 11, poz. 160, oraz wyrok TK z 20 VII 2010 r., sygn. K 17/08, OTK-A 2010, nr 6, poz. 61.

17 Dz.U. Nr 164, poz. 1588, dalej: rozp.n.z. 
w zw. z art. 1 ust. 2 u.p.z.p. doprowadziła TK do wniosku o deklaratoryjnym charakterze decyzji wydanej na postawie art. 61 u.p.z.p. Trybunał zauważa jednak, że wyznaczenie mniejszego lub większego obszaru może w konkretnych przypadkach decydująco wpływać na kształt decyzji o warunkach zabudowy. Ta ostatnia uwaga pozwala zatem na wykazanie zakresu i granic władztwa planistycznego, które, jak widać, mieści się w ramach wyjątkowo dużego uznania administracyjnego.

Zatem z możliwości zmiany przeznaczenia terenu zarezerwowanego wyłącznie dla miejscowych planów wywodzi się wniosek o deklaratoryjnym charakterze decyzji o warunkach zabudowy i zasadniczo stanowisko to jest dominujące ${ }^{18}$. W doktrynie prezentowane są jednak także odmienne podejścia do tego aktu. Mianowicie M. Szewczyk wskazuje, że decyzja o warunkach zabudowy składa się z dwóch rozstrzygnięć. Pierwsze dotyczy orzeczenia o legalności albo nielegalności konkretnej inwestycji w określonym miejscu, które to rozstrzygnięcie następuje w wyniku konkretyzacji przepisów ustawowych i ma charakter deklaratoryjny. Jednak zgodnie $z$ art. 4 ust. 2 u.p.z.p. przedmiotem rozstrzygnięcia jest określenie sposobu zagospodarowania i zabudowy terenu, a jakakolwiek jego zmiana, zgodnie z art. 59 u.p.z.p., wymaga zgody organu, co dowodzi istnienia ustawowego zakazu samoistnego dokonywania zmiany zagospodarowania terenu. Potwierdza to ust. 3 wskazanego artykułu przewidujący uprawnienia władcze organu w celu przywrócenia stanu sprzed naruszenia prawa. I właśnie przedmiotem drugiego rozstrzygnięcia jest uchylenie tego zakazu, które to, zdaniem M. Szewczyka, ma charakter konstytutywny, skutek taki ma bowiem każda decyzja uchylająca czy zmieniająca prawo ${ }^{19}$. Zaprezentowany pogląd, mimo że nie jest powszechnie akceptowany, dowodzi, jak złożonym aktem administracyjnym jest decyzja o warunkach zabudowy i jak trudne jest uchwycenie jej istoty. Dla celów niniejszego opracowania za najważniejszą cechę rozróżniającą oba analizowane akty uznać jednak należy możliwość zmiany przeznaczenia terenu, która przypisana jest wyłącznie miejscowym planom, choć tezy o jej kształtującym charakterze również nie pozostają bez wpływu na ostateczny wynik rozważań.

Wracając jednak do istotnego elementu odróżniającego, zmiany przeznaczenia terenu, która może nastąpić wyłącznie poprzez akt prawa miejscowego, wskazać trzeba na konsekwencje wynikające z odmiennej

\footnotetext{
${ }^{18}$ Zob. J. Goździewicz-Biechońska, op. cit., s. 100 i n.

${ }^{19}$ Z. Leoński, M. Szewczyk, M. Kruś, op. cit., s. 193-195.
} 
właściwości rzeczowej. Mianowicie rada gminy, jako organ uprawniony do uchwalania miejscowych planów, ma o wiele większe kompetencje planistyczne niż organ wykonawczy podstawowej jednostki samorządu terytorialnego. Takie unormowanie pozycji tego aktu normatywnego wypływa zapewne $\mathrm{z}$ faktu, że jest on podstawowym elementem ustalania ładu przestrzennego. Wniosek ten można wywodzić $\mathrm{z}$ art. 7 ust. 1 pkt 1 Ustawy z dnia 8 marca 1990 r. o samorządzie gminnym ${ }^{20}$, wskazującego jako zadanie własne kwestię ładu przestrzennego. A trudno mówić o racjonalnym kształtowaniu przestrzeni publicznej za pomocą tysięcy pojedynczych aktów charakteryzujących się sporą uznaniowością. Z kolei decyzja o warunkach zabudowy nie może zmienić przeznaczenia terenu, co więcej, zgodnie z art. 56 u.p.z.p. ma charakter decyzji związanej w tym sensie, że organ nie może odmówić jej wydania, jeśli nie stwierdzi niezgodności żądania wnioskodawcy z przepisami prawa. A contrario można by wnosić, że w miejscowym planie gmina może dowolnie zmieniać przeznaczenie gruntów, który to pogląd nie wydaje się wszakże uzasadniony. $Z$ jednej strony ustalenia studium wiążą gminę przy sporządzaniu miejscowych planów, z drugiej - wykładnia funkcjonalna nakazuje uwzględnianie przepisów ogólnych ustawy o planowaniu i zagospodarowaniu przestrzennym, mających charakter nadrzędny wobec dalszych postanowień ustawy. Autor ma tu na myśli przede wszystkim takie pojęcia jak ład przestrzenny i zrównoważony rozwój, czy też inne podstawowe zasady wynikające z art. 1 u.p.z.p.

Kolejnym istotnym elementem odróżniającym analizowane akty jest procedura ich wydawania. Zdecydowanie bardziej transparentny i zapewniający dostęp społeczności lokalnych do prac planistycznych jest tryb uchwalania miejscowych planów. $Z$ kolei aby aktywnie uczestniczyć przy wydawaniu decyzji o warunkach zabudowy, należy wykazać interes prawny na zasadach ogólnych określonych w Kodeksie postępowania administracyjnego ${ }^{21}$, bowiem ustawa o planowaniu i zagospodarowaniu przestrzennym nie określa odrębnie stron postępowania. Odwołanie się do instytucji interesu prawnego powoduje znaczące ograniczenie podmiotowe osób uczestniczących przy jej wydawaniu i powoduje, że wiele z nich, które będą miały wyłącznie interes faktyczny, nie tylko nie będą mogły wypowiedzieć się na temat nowej zabudowy, ale także często nie będą nawet poinformowane o tym, że może nastąpić zamiana sposobu

${ }^{20}$ Tekst jedn. Dz.U. 2016, poz. 446.

${ }^{21}$ Ustawa z dnia 14 VI 1960 r. Kodeks postępowania administracyjnego (tekst jedn.

Dz.U. 2013, poz. 267 ze zm.), dalej „k.p.a.”. 
zagospodarowania i zabudowy nieodległej działki gruntu. Zasadniczo słuszny wydaje się pogląd wyrażony w orzecznictwie, że w każdej sprawie o ustalenie warunków zabudowy o interesie prawnym, a co za tym idzie, o przymiocie strony innej niż inwestor decydują okoliczności konkretnej sprawy związane $\mathrm{z}$ rodzajem, rozmiarem oraz stopniem i zakresem uciążliwego oddziaływania zamierzonej inwestycji na otoczenie. W każdej konkretnej sprawie tego rodzaju organ wydający decyzję, ustalając krąg osób, które mają interes prawny w sprawie, musi badać, czy a jeśli tak, to jak daleko - sięgać będzie obszar oddziaływania planowanej inwestycji oraz jej charakter ${ }^{22}$. Należy przy tym wskazać, że przedmiotowa ustawa nie definiuje pojęcia "obszar oddziaływania” i ustalenie jego granic cechuje spora dyskrecjonalnośćc ${ }^{23}$. Nie budzi natomiast wątpliwości fakt, że stroną takiego postępowania będą właściciele oraz użytkownicy wieczyści nieruchomości sąsiadujących z nieruchomościa, na której planowana (realizowana) jest inwestycja ${ }^{24}$. Ograniczenie uczestnictwa w kształtowaniu ładu przestrzennego odnosi się zatem w praktyce co do zasady do właścicieli działek sąsiednich, a nie tych, którzy znajdują się $\mathrm{w}$ „obszarze analizowanym”. Za słuszne, zdaniem autora, należy uznać stanowisko sądu administracyjnego, iż ratio legis art. 61 u.p.z.p., a w szczególności ust. 1 pkt 1 tego przepisu, jest zagwarantowanie ładu przestrzennego, co przemawia za szerokim pojęciem sąsiedztwa uwzględniającego wpływ inwestycji na otoczenie w sensie urbanistycznym. $Z$ tego względu okoliczność, że działki, na których znajdują się budynki, do których to nawiązuje analiza, nie są dostępne z tej samej drogi co działka inwestycyjna, nie oznacza, iż działki te są pozbawione waloru "działki sąsiedniej” w rozumieniu art. 61 ust. 1 pkt 1 u.p.z.p. ${ }^{25}$

Jednakże nawet szeroko rozumiane sąsiedztwo urbanistyczne nie równoważy braku możliwości wypowiedzenia się każdego członka

${ }^{22}$ Wyrok Wojewódzkiego Sądu Administracyjnego (WSA) w Poznaniu z 27 I 2011 r., sygn. II SA/Po 378/10 (orzeczenie prawomocne), LEX nr 953358.

${ }^{23}$ Definicję obszaru oddziaływania obiektu zawiera art. 3 pkt 20 Ustawy z dnia 7 VII 1994 r. Prawo budowlane (tekst jedn. Dz.U. 2016, poz. 290 ze zm.), brak jednak jej odpowiednika w u.p.z.p.

${ }^{24}$ Zob.: wyrok WSA w Poznaniu z 17 I 2013 r., sygn. IV SA/Po 842/12 (orzeczenie prawomocne), LEX nr 1274844; wyrok WSA w Poznaniu z 7 XI 2012 r., sygn. IV SA/Po 867/12 (orzeczenie prawomocne), LEX nr 1242252; wyrok NSA z 8 III 2005 r., sygn. OSK 682/04, LEX nr 176144; uchwała NSA z 25 IX 1995 r., sygn. VI SA 13/1995, ONSA 1995/4/154, LEX nr 10650; uchwała NSA z 4 XII 1995 r., sygn. VI SA 20/95, ONSA 1996/2/54, LEX nr 23844.

${ }^{25}$ Zob. wyrok WSA w Warszawie z 16 II 2012 r., sygn. IV SA/Wa 1865/11 (orzeczenie prawomocne), LEX nr 1139654. 
wspólnoty lokalnej, i nie tylko. To szczegółowe określenie stron postępowania w sprawie wydania decyzji o warunkach zabudowy wskazuje, jak znacząco w jej przypadku zostaje ograniczony zakres partycypacji społecznej, o ile w ogóle można o niej mówić. Wydaje się, że w takim przypadku chodzi bardziej o prawa i obowiązki właścicieli nieruchomości sąsiednich, w tym o ochronę prawa własności, a nie o wpływ na politykę przestrzenną. Następuje tu zatem odebranie członkom wspólnoty prawa uczestnictwa w procedurze planistycznej na rzecz ochrony indywidualnego interesu ${ }^{26}$.

Kończąc tę część rozważań, warto wskazać jeszcze jeden aspekt. Nieodłącznym elementem związanym $z$ uchwaleniem miejscowego planu z punktu widzenia konsekwencji finansowanych dla budżetu gminy jest kwestia renty planistycznej, na co wskazuje ab initio art. 36 ust. 4 u.p.z.p. Mianowicie, jeżeli w związku z uchwaleniem planu miejscowego albo jego zmianą wartość nieruchomości wzrosła, a właściciel lub użytkownik wieczysty zbywa tę nieruchomość, to wójt, burmistrz albo prezydent miasta pobiera jednorazową opłatę ustaloną $\mathrm{w}$ tym planie, określoną w stosunku procentowym do wzrostu wartości nieruchomości. Powstaje jednak pytanie, czy renta planistyczna może zostać naliczona także w przypadku wydania decyzji o warunkach zabudowy. Formalnie na taką możliwość wskazuje art. 63 ust. 3 zd. 1 u.p.z.p., który stwierdza, że jeżeli decyzja o warunkach zabudowy wywołuje skutki, o których mowa w art. 36, to przepisy art. 36 oraz art. 37 stosuje się odpowiednio. Wykładnia językowa jest jednak korygowana zawężająco przez orzecznictwo sądów administracyjnych, które dowodza, że w tym wypadku odpowiednie stosowanie oznacza brak stosowania ${ }^{27}$.

Ostatecznie przeprowadzone analizy doprowadzają do wniosku, że decyzja o warunkach zabudowy stanowi swoistą namiastkę miejscowego planu, jednak nie zastępuje go. $Z$ kolei brak co do zasady obligatoryjności sporządzania miejscowych planów, poza wyjątkami przewidzianymi przepisami odrębnymi, wskazuje, iż gmina w ramach samodzielności planistycznej ma możliwość wyboru i decydowania o jego uchwaleniu, gdyż zawsze może alternatywnie sięgnąć po inny instrument prawny, tj. decyzję o warunkach zabudowy. Przy tym ta ostatnia nie może być wydana z urzędu, ale jedynie na wniosek.

${ }^{26} \mathrm{O}$ relacjach między interesem publicznym i prywatnym zob. np. J. Stelmasiak, Interes indywidualny a interes publiczny w obszarze specjalnym o charakterze ekologicznym, Rzeszów 2013.

${ }^{27}$ Zob. wyrok NSA z 22 VII 2011 r., sygn. II OSK 1193/10, LEX nr 1083573. 


\section{Minimalny i maksymalny obszar miejscowego planu}

W kwestiach dotyczących obszaru, jaki może obejmować miejscowy plan oraz decyzja o warunkach zabudowy, ustawodawca nie wypowiada się wprost, stąd wykładnia językowa musi zastać wsparta innymi regułami interpretacji tekstów prawnych, przede wszystkim wykładnią funkcjonalną ${ }^{28}$. W przypadku pierwszego z tych dokumentów art. 14 ust. 2 u.p.z.p. wskazuje jedynie, że integralną częścią uchwały o przystąpieniu do sporządzania miejscowego planu jest załącznik graficzny przedstawiający granice obszaru objętego projektem planu. I właśnie ten załącznik, jako jedyny, określa zasięg terytorialny planu i wiąże gminę przy jego sporządzaniu. Oznacza to, że dalsze prace planistyczne mogą obejmować tylko obszar wskazany w uchwale. Wszelkie legalne zmiany wskazanego w uchwale "intencyjnej” obszaru wymagają podjęcia nowej uchwały ${ }^{29}$. Wykładnia językowa wprowadza zatem wyłącznie wymóg oznaczenia granic miejscowego planu, sama ustawa nie precyzuje wprost innych determinant terytorialnych, wskazuje jedynie skalę, w jakiej ma być on sporządzany. Prima facie wydaje się, że z jednej strony objęty nim może zostać niemalże dowolny obszar znajdujący się w granicach gminy, z drugiej natomiast - tak niewielka jej część, że właściwą jednostką dla pomiaru jej powierzchni byłyby metry kwadratowe. Przy określaniu maksymalnego obszaru możliwego do objęcia planem należy wskazać, że jedną z istotnych cech planu jest

\footnotetext{
${ }^{28}$ S. Wronkowska, Z. Ziembiński, Teoria państwa i prawa, s. 166 i n.

${ }^{29}$ Zob. wyrok NSA z 21 VII 2010 r., sygn. II OSK 964/10, LEX nr 694436, w którym stwierdzono, że:

1. Skoro u.p.z.p. wyraźnie stanowi, iż załącznik graficzny jest integralną częścią uchwały o przystąpieniu do zmiany miejscowego planu zagospodarowania przestrzennego, to rada gminy jest tym przepisem prawa związana i nie może decydować, czy istnieje potrzeba sporządzenia takiego załącznika graficznego, czy nie, w zależności od charakteru zmian, które zamierza wprowadzić do planu miejscowego. Wykładnia celowościowa art. 14 ust. 2 u.p.z.p. nie może prowadzić do wniosków, które pozostają w oczywistej sprzeczności z jego wykładnią językową.

2. Funkcją załącznika graficznego do uchwały o przystąpieniu do sporządzania lub zmiany miejscowego planu zagospodarowania przestrzennego jest jednoznaczne wyznaczenie granic obszaru objętego projektem planu lub projektem jego zmiany. Ustawa nie określa wymagań co do skali mapy, która stanowić ma taki załącznik. Wyznaczenie tych granic na odpowiedniej mapie powinno jednak być na tyle precyzyjne, aby nie powstały wątpliwości, czy dana nieruchomość została objęta procedurą planistyczną.

3. Uchwała musi precyzyjnie określać, które nieruchomości zostaną objęte planem lub jego zmiana, aby możliwe było ustalenie, czy na tych właśnie nieruchomościach planowana jest lokalizacja inwestycji celu publicznego.
} 
jego precyzyjność przejawiająca się w możliwości dokładnego określenie funkcji i cech objętego nim terenu. Jeśli obszar ten byłby zbyt duży, to wymagałby innej skali, która już wskazanej precyzji nie mogłaby gwarantować. Pogląd ten wydaje się potwierdzać wykładnia historyczna. Obecnie miejscowe plany co do zasady sporządzane są w skali $1: 1000^{30}$, wcześniej gminy same ją ustalały, stąd zdarzało się, że sporządzano je w skali $1: 5000$, a nawet $1: 10000$. Dziś miejscowe plany nie maja mieć zatem ramowego charakteru, co więcej, „W szczególnie uzasadnionych przypadkach" dopuszcza się stosowanie map w skali $1: 500$ (np. centrum miast). Pogląd ten potwierdza najnowsze orzecznictwo, wskazując, że sporządzenie planu miejscowego w skali 1 : 5000 zamiast w skali $1: 1000$, która wskazana jest $\mathrm{w}$ art. 16 ust. 1 u.p.z.p., stanowi istotne naruszenie ustawowo określonych zasad sporządzania planu w rozumieniu art. 28 ust. 1 u.p.z.p. Nie zmniejsza wagi tego naruszenia sporządzenie planu na aktualnej mapie odzwierciedlającej stan prawny, znajdującej się w zasobie geodezyjnym i kartograficznym i naniesienie granic obszarów i terenów o różnym przeznaczeniu oraz linii rozgraniczających na kopiach map ${ }^{31}$.

Dyrektywy zastosowania odpowiedniej skali normuje akt wykonawczy do u.p.z.p. Analizując szczegółowo postanowienia Rozporządzenia Ministra Infrastruktury z dnia 26 sierpnia 2003 r. w sprawie wymaganego zakresu projektu miejscowego planu zagospodarowania przestrzennego ${ }^{32}, Z$. Niewiadomski dochodzi do wniosku, że ustawodawca dopuszcza wydawanie decyzji o pozwoleniu na budowę zasadniczo tylko na podstawie planów sporządzanych w skali $1: 1000^{33}$, wyjątkowo w skali $1: 500$ i $1: 2000^{34}$. Zgodnie z $\& 6$ ust. 2 tego rozporządzenia skala najmniejsza może być stosowana dla obszarów intensywnej zabudowy oraz przestrzeni publicznej. Tym samym pojawiają się pośrednio dwa kryteria determinujące wielkość obszaru objętego pojedynczym

${ }^{30}$ Zob. także art. 4 ust. 1e pkt 1 i 2 Ustawy z dnia 17 V 1989 r. Prawo geodezyjne i kartograficzne (tekst jedn. Dz.U. 2015, poz. 520 ze zm.), który wskazuje na skalę sporządzanych map, które pokrywają się z tymi wskazanymi w art. 16 ust. 1 u.p.z.p.

${ }^{31}$ Wyrok NSA z 6 VII 2010 r., sygn. II OSK 871/10, LEX nr 673892.

${ }^{32}$ Dz.U. Nr 164, poz. 1587.

${ }^{33}$ Jednak w orzecznictwie wskazuje się, że skala 1 : 2000 stosowana bez wyraźnego uzasadnienia nie stanowi podstawy do stwierdzenia nieważności planu, zob. wyrok WSA w Krakowie z 19 III 2012 r., sygn. II SA/Kr 1921/11 (orzeczenie nieprawomocne), LEX nr 1138578.

${ }^{34}$ Planowanie izagospodarowanie przestrzenne. Komentarz, pod red. Z. Niewiadomskiego, Warszawa 2009, s. 163. 
planem, przy czy oba mają charakter nieostry: intensywna zabudowa oraz przestrzeń publiczna. $Z$ punktu widzenia interesu publicznego wyrażanego poprzez ład przestrzenny na tym etapie rozważań można postawić wstępną tezę, że obszar o intensywnej zabudowie wymaga uchwalenia miejscowego planu. Takie rozumienie przepisów ustawy z pewnością gwarantuje zrealizowanie jednego z jej najważniejszych celów, tj. kreowania stanu ładu przestrzennego i zrównoważonego rozwoju. A contrario decyzja o warunkach zabudowy powinna obejmować w skrajnym ujęciu jeden obiekt budowlany, ewentualnie wraz z budynkami pomocniczymi, a nie ich większą liczbę. Tym samym pojęcie "obszar intensywnej zabudowy" determinowałoby zastosowanie określonej formy prawnej działania organu w ramach władztwa planistycznego. W świetle powyższego zaproponować można przyjęcie takiego stanowiska, że wszędzie tam, gdzie go się nie przewiduje, ład przestrzenny i warunki zabudowy mogą być wyznaczone poprzez wydanie decyzji o warunkach zabudowy, o ile spełnione zostaną przesłanki z art. 61 ust. 1 u.p.z.p., której to konstatacji również nie można przyjąć bezkrytycznie.

Inną determinantą maksymalnej powierzchni miejscowych planów, empirycznie potwierdzalna, może być fizyczna wielkość miejscowego planu. Chodzi o odpowiedź na pytanie, jaki zasięg będzie miała mapa w skali 1 : 1000, na której będą mogli pracować urbaniści. Skoro jeden metr mapy to jeden kilometr w rzeczywistości, to wydaje się, że przedmiotem jednorazowego opracowania będą mapy o długość najwyżej kilku metrów, a więc obejmą najwyżej kilka kilometrów kwadratowych obszaru gminy. Przesłanki prakseologiczne wskazują bowiem na to, iż na mapach zasadniczych obejmujących większy obszar trudno będzie pracować, nie wspominając o ich przechowywaniu. Dopiero zmiana skali umożliwia objęciem planem większego obszaru, w skrajnym przypadku całej gminy. Jednak maksymalna skala 1 : 2000 wskazana ustawą zdaje się to uniemożliwiać. Oczywiście, skorzystanie z cyfrowego zapisu daje niemalże nieograniczone możliwości, jednak również i tu należy odnieść się do dyrektyw celowościowych.

Powyższe rozważania dotyczą przede wszystkim maksymalnej powierzchni, jaką moga, czy też powinny, objąć miejscowe plany. Natomiast w kwestii minimalnego obszaru miejscowego planu ustawodawca nie zawarł wprost żadnej wskazówki. Nie oznacza to, że sięgnięcie do innych reguł wykładni nie pozwoli na dokonywanie uogólnień w tym zakresie. Na tym tle za bardzo interesujące należy uznać orzeczenie 
WSA w Gdańsku z 12 października 2011 r. ${ }^{35}$, w którym sąd dochodzi do wniosku, że wszczynanie kosztownej i czasochłonnej procedury planistycznej dla terenu jednej nieruchomości otoczonej zabudowanymi działkami winno znajdować swoje uzasadnienie, bowiem w takiej sytuacji co do zasady istnieje możliwość zagospodarowania terenu w sposób zapewniający ład przestrzenny przez wydanie decyzji o warunkach zabudowy. Odnosząc się do przepisów u.p.z.p., należy wskazać, iż jedną z przesłanek wszczęcia procedury uchwalania planu jest analiza dotycząca zasadności jego sporządzenia. Wydaje się, że właśnie ta instytucja prawna może wpływać na zasięg miejscowego planu. Sąd słusznie zauważa, iż uchwalenie planu dla jednej nieruchomości może być uzasadnione, przykładowo, przeznaczeniem nieruchomości na cele publiczne, a więc de facto najpierw z wywłaszczeniem faktycznym, a następnie klasycznym. Inny powód to zamiar ukształtowania przez gminę przestrzeni na tej nieruchomości w sposób odbiegający od nieruchomości sąsiednich. W takiej jednak sytuacji organ podejmujący uchwałę winien szczegółowo uzasadnić przyczynę takiego właśnie ograniczenia prawa własności tej nieruchomości. Sąd przedstawia także jeszcze jeden istotny argument. Mianowicie ograniczenie terenu planu zagospodarowania przestrzennego do jednej nieruchomości (która może składać się kilku działek) uniemożliwia porównanie na gruncie postanowień planu sytuacji właścicieli tej nieruchomości z sytuacją właścicieli pobliskich nieruchomości, czego wprawdzie jeszcze nie należy uznawać za naruszenie zasad jego sporządzania, niemniej przyjęcie takich założeń planistycznych tym bardziej wymaga szczegółowego umotywowania. Nadto należałoby wskazać, czy ewentualna zmiana przeznaczenia nieruchomości nie ogranicza prawa własności nieruchomości w sposób nadmierny i nieuzasadniony. Tym samym uchwalenie miejscowego planu dla jednej nieruchomości, która poprzednio nie była objęta jakimkolwiek planem, a której sposób zabudowy i zagospodarowania bez żadnych wątpliwości można ustalić w drodze decyzji o warunkach zabudowy, wydaje się z punktu widzenia przesłanek prakseologicznych i ekonomicznych niezasadne. Słusznie wskazał sąd, że jest to kosztowna i długotrwała procedura, a cel można osiągnąć w sposób szybszy i oszczędniejszy. Niemniej, co wymaga pokreślenia, nie sposób uznać takiego działania gminy za naruszające prawo, tym bardziej w sposób

${ }^{35}$ Wyrok WSA w Gdańsku z 12 X 2011 r., sygn. II SA/Gd 265/11 (orzeczenie prawomocne), LEX nr 1125244. 
istotny, który mógłby doprowadzić do uznania uchwały rady w przedmiocie uchwalenia planu za nieważną.

Przeprowadzone rozważania doprowadzają zatem do wniosku, że zasięg miejscowego planu ograniczany jest m.in. skalą i wielkością mapy zasadniczej, na której jest sporządzany. Jeśli uznać, że racjonalny językowo ustawodawca zrezygnował świadomie ze wskazywania powierzchni, uwzględniając jedynie kryterium skali, to racjonalność aksjologiczna nakazuje odwołać się do systemu wartości chronionych w u.p.z.p. Oczywiste jest odwołanie się do pojęć zawartych w art. 1 ust. 1 in fine u.p.z.p., czyli ładu przestrzennego i zrównoważonego rozwoju. $\mathrm{W}$ konsekwencji pojawia się istotne pytanie, czy objęcie miejscowymi planami bardzo małych terenów umożliwia ich realizację. Wprowadzanie ładu nawet przy niewielkim obszarze planu jest możliwe, ale wynikać musi z zastanego, konkretnego stanu faktycznego. Niekiedy bowiem jego zbyt mały obszar nie umożliwi uwzględnienia większej części przestrzeni stanowiącej całość urbanistyczną. Tylko wypowiedzenie się co do całości zagwarantuje uwzględnienie wszelkich determinant, natomiast uchwalenie planu punktowo, przy ignorowaniu terenów o takim samym przeznaczeniu, a np. objętych już planem, może doprowadzić do nadużyć.

Konkludując, niewłaściwe wydaje się tworzenie dwóch lub więcej odrębnych planów dla terenów jednorodnych, które powinny być objęte jednym aktem. Uzasadniać to może odmienne przeznaczenie terenu lub inne istotne odstępstwo, a brak takich przesłanek jest $\mathrm{w}$ istocie nadużyciem władztwa planistycznego, również w sferze finansowej.

\section{Minimalny i maksymalny obszar w decyzji o warunkach zabudowy}

Wskazanie determinant wielkości obszaru objętego postępowaniem w sprawie wydania decyzji o warunkach zabudowy, szczególnie jej maksymalnego wymiaru, jest o wiele trudniejsze. Co ciekawe, art. 4 ust. 2 u.p.z.p. wskazuje wprost, że wydaje się ją dla "terenu”, a art. 61 również zasadniczo posługuje się tym terminem, który jednak nie jest w ustawie definiowany. Dopiero ust. 7 pkt 2 art. 61 u.p.z.p. wskazuje, iż rozp.n.z. określić ma wymagania w sprawie wielkości powierzchni zabudowy w stosunku do powierzchni „działki” albo „terenu”. Podobne 
alternatywne rozróżnienie wprowadza wielokrotnie Prawo budowlane ${ }^{36}$. Natomiast $\S 3$ ust. 1 rozp.n.z. stanowi ab initio, że w celu ustalenia wymagań dla nowej zabudowy i zagospodarowania terenu właściwy organ wyznacza wokół działki budowlanej, której dotyczy wniosek o ustalenie warunków zabudowy, obszar analizowany. Tym samym wykładnia językowa oraz funkcjonalna wskazują, że właściwym obszarem dla analizowanej decyzji jest w praktyce konkretna działka, która ma podlegać zabudowie, czyli działka budowlana. Definicja działki budowlanej zawarta jest $\mathrm{w}$ art. 2 pkt 12 u.p.z.p. i zgodnie z nią jest to nieruchomość gruntowa lub działka gruntu, której wielkość, cechy geometryczne, dostęp do drogi publicznej oraz wyposażenie w urządzenia infrastruktury technicznej spełniają wymogi realizacji obiektów budowlanych wynikające z odrębnych przepisów i aktów prawa miejscowego. Inny bliski i ważny termin to "działka gruntu”, którą zgodnie z art. 4 pkt 3 u.g.n. jest niepodzielona, ciągła część powierzchni ziemskiej stanowiąca część lub całość nieruchomości gruntowej. Mimo że rozumienie to nie powinno być stosowane wprost w planowaniu przestrzennym, to jednak jako zawarte w innej ustawie głównej, powiązanej z problematyką planowania przestrzeni, powinno być co najmniej brane pod uwagę.

Powyższe rozważania prowadzą do wniosku, że utożsamienie pojęć "teren" $\mathrm{i}$ "działka" z pojęciem działki budowlanej wydaje się założeniem racjonalnym. Na takie rozumienie wskazuje przede wszystkim wykładnia funkcjonalna, bowiem $\mathrm{z}$ „zasady dobrego sąsiedztwa” wynika, że teren czy działka, dla której wydaje się decyzję, jest otoczony "działkami sąsiednimi", w tym dostępnymi z tej samej drogi publicznej. Tym samym teren ten ma określone granice, które są ujęte na zasadniczych mapach geodezyjnych, a zgodnie $z$ art. 52 ust. 1 pkt $1 \mathrm{w}$ zw. $z$ art. 64 ust. 1 u.p.z.p. wnioskodawca ma wskazać granice terenu objętego wnioskiem. Skoro ustawa posługuje się bliżej niedefiniowanym terminem "teren” oraz "działka” w liczbie pojedynczej, to oznacza to, że mapa ma wskazywać wyraźnie tylko jeden konkretny obszar, będący w uproszczeniu jedną działka, najczęściej budowlana, na co wskazuje rozporządzenie wydane na podstawie art. 61 ust. 6 i 7 u.p.z.p. Zresztą identyfikacja terenu następuje poprzez wskazanie oznaczenia geodezyjnego - obrębu i arkusza, a także numeru geodezyjnego działki oraz jej powierzchni. Szczegółowo kwestie te określa Prawo geodezyjne i kartograficzne, wskazując, że mapy zasadnicze zawierają

${ }^{36}$ Zob. art. 6, art. 9 ust. 3, art. 30 ust. 3, art. 33 ust. 1 i in. Ustawy z dnia 7 VII 1994 r. Prawo budowlane (tekst jedn. Dz.U. 2016, poz. 290). 
aktualne informacje o elementach ewidencji gruntów i budynków, która to $\mathrm{z}$ kolei jest zbiorem informacji m.in. o osobach władających grunta$\mathrm{mi}^{37}$. Nie jest jednak celem niniejszego opracowania dalsze analizowanie zauważonych nieścisłości, zaś dla jego potrzeb przyjmuje się, że decyzja o warunkach zabudowy dotyczy niepodzielonej część powierzchni ziemskiej stanowiącej część lub całość nieruchomości gruntowej.

Zasadnicze zagadnienie, które będzie dalej badane, dotyczy pytań o minimalny i maksymalny obszar, jaki może objąć decyzja o warunkach zabudowy. Odpowiedź na pierwsze wydaje się prostsza, mimo że nie pozwoli na wskazanie konkretnych wymiarów. Mianowicie przy braku miejscowego planu, który wprost określa minimalną powierzchnię działek budowlanych ${ }^{38}$, stosowane może być kryterium funkcjonalne sprowadzające się do odpowiedzi na pytanie, czy wskazany we wniosku teren umożliwia zrealizowanie zamierzenia inwestycyjnego. W przypadku nowej zabudowy przesądzają o tym z jednej strony przepisy techniczne wydane na podstawie Ustawy z dnia 7 lipca 1994 r. Prawo budowlane, w szczególności rozporządzenia wykonawcze wydane na podstawie art. 7 ust. 2 pkt 1 tego aktu ${ }^{39}$, normujące m.in. minimalne odległości sytuowania obiektów budowlanych, w tym mieszkalnych, od granicy działki. Z drugiej strony wspomnieć należy o innym akcie generalnym, tj. studium uwarunkowań i kierunków zagospodarowania przestrzennego gminy, które poprzez kierunki i wskaźniki dotyczące zagospodarowania, np. wskazujące konkretne, minimalne powierzchnie działek, również determinuje wielkość przyszłych działek budowlanych. Jest ono jednak aktem o charakterze wewnętrznym i wiąże formalnie organy gminy tylko przy sporządzaniu miejscowych planów, a nie przy wydawaniu decyzji o warunkach zabudowy. Mimo że zakres i możliwości oddziaływania studium na treść tej decyzji ciągle są przedmiotem sporów w doktrynie ${ }^{40}$, to odniesienie się do jego postanowień pozwala chociażby pomocniczo wskazać ich minimalną powierzchnię. Wydaje się, że racjonalne wykorzystanie na określone cele, np. budowlane, stanowić będzie wskaźnik jej minimalnej powierzchni.

${ }^{37}$ Art. 2 pkt 7 i 8 Ustawy z dnia 17 V 1989 r. Prawo geodezyjne i kartograficzne.

${ }^{38}$ Art. 15 ust. 2 pkt 14 u.p.z.p.

${ }^{39} \mathrm{~Np}$. Rozporządzenie z dnia 12 IV 2002 r. w sprawie warunków technicznych, jakim powinny odpowiadać budynki i ich usytuowanie (tekst jedn. Dz.U. 2015, poz. 1422).

${ }^{40}$ Zob. np. W. Kisiel, Relacja między studium kierunków i uwarunkowań zagospodarowania przestrzennego gminy a decyzja o warunkach zabudowy (uwagi do glosy Jerzego Kopyry), „Samorząd Terytorialny" 2011, nr 11, s. 80 i n. 
$\mathrm{O}$ wiele bardziej interesujące jest natomiast zagadnienie maksymalnego terenu, jakim może zostać objęte postępowanie w sprawie wydania decyzji o warunkach zabudowy. Jeśli bowiem jedynym kryterium będzie objęcie nim pojedynczej działki oznaczonej na mapie zasadniczej, to o jej obszarze decydowałoby wyłącznie cywilnoprawne ujęcie wyodrębnienia działki gruntu. Ograniczenie się do tego kryterium spowoduje, że teoretycznie analizowana decyzja może objać obszar nawet kilku hektarów. Jeśli zważyć, że załącznik graficzny do wniosku o jej wydanie ma m.in. wskazywać gabaryty projektowanych obiektów budowlanych, to przy tak wielkim terenie może to oznaczać wydanie warunków zabudowy i zagospodarowania dla całych osiedli mieszkaniowych. Praktyka podpowiada, że takie sytuacje w Polsce miały już miejsce.

Teoretycznie taka pojedyncza działka może mieć długość kilkuset metrów lub nawet kilku kilometrów. Konsekwencje ustalania warunków zabudowy dla tak dużej działki są różnorakie i daleko idące. Przede wszystkim znacząco rozszerza się obszar analizowany. Jedna z podstawowych zasad jego określenia, czyli przynajmniej trzykrotność frontu działki objętej wnioskiem, powoduje, że wyrysowany okręg na kopii mapy zasadniczej może mieć średnicę kilku kilometrów. Dodatkowo ostatnio w orzecznictwie pojawiają się tezy, że nie można w sposób formalistyczny ograniczać sposobu wyznaczania granic obszaru analizowanego i za prawidłowy przyjmować wyłącznie taki, który uwzględnia minimalne odległości, gdyż racjonalność urbanistyczna może przemawiać za ich powiększeniem ${ }^{41}$. Tak wielki obszar może obejmować i najczęściej obejmuje tereny o różnym przeznaczeniu, a już z pewnością o odmiennych sposobach zagospodarowania i zabudowy. Tym samym, jeśli np. w obszarze analizowanym o funkcji mieszkaniowej wysokość zabudowy w znakomitej większości wynosi dwie kondygnacje naziemne w formie zabudowy wolnostojącej, a znajdzie się tylko jeden, bądź zaledwie kilka budynków trzykondygnacyjnych, wielorodzinnych, odległych od działki wnioskodawcy przykładowo o dwa kilometry i znajdujących się nadto po przeciwnej stronie drogi publicznej rozdzielającej różne kwartały zabudowy, to tak wielka działka i wyznaczony legalnie wokół niej obszar analizowany pozwalają w pewnym zakresie odnieść się do

${ }^{41}$ Zob. wyrok WSA w Białymstoku z 13 III 2013 r., sygn. II SA/Bk 1016/12 (orzeczenie prawomocne), LEX nr 1302954; wyrok WSA w Łodzi z 20 XI 2012 r., sygn. II SA/Ld 57/12 (orzeczenie prawomocne), LEX nr 1241635; wyrok WSA w Poznaniu z 24 X 2012 r., sygn. II SA/Po 154/12 (orzeczenie prawomocne), LEX nr 1241152. 
zabudowy zdecydowanie mniejszościowej. W ten sposób może dojść do dyskusyjnej intensyfikacji zabudowy, tym bardziej jeśli wniosek dotyczy budynków mieszkalnych w zabudowie szeregowej. Istniejące zatem cywilnoprawne wyodrębnienie działek gruntu może spowodować, że działka na obrzeżach miasta znajdzie poprzez instytucję obszaru analizowanego oparcie na jego bardziej zurbanizowanej części, potencjalnie nawet z zabudową śródmiejską. Nadto w orzecznictwie wskazuje się na faktyczną możliwość rozszerzenia obszaru analizowanego powyżej minimalnych granic wskazanych w rozporządzeniu, jednakże powinno być to uzasadnione racjonalnością urbanistyczną i ładem przestrzennym $^{42}$. Ta kompetencja wprowadza wiele dodatkowych dyskrecjonalnych uprawnień dla organów administracji publicznej. Sytuacja staje się tym bardziej dyskusyjna, jeśli otaczająca zabudowa jest chaotyczna i nie pozwala na ustalenia wzorca lub też czyni go jeszcze bardziej wieloznacznym. A przecież spełnienie wymogów formalnych z art. 61 ust. 1 u.p.z.p. obliguje organ do wydania decyzji ${ }^{43}$.

Konsekwencje takiej obszarowo rozległej decyzji o warunkach zabudowy są wielorakie. Niemożliwe jest, zdaniem autora, budowanie ładu przestrzennego i zrównoważonego rozwoju poprzez akty administracyjne indywidualne na takim poziomie, jak czyni to miejscowy plan, a nawet zasadne jest pytanie, czy na ich podstawie w ogóle możliwe jest jego należyte kształtowanie. Aby w pełni zrozumieć doniosłość obowiązywania miejscowego planu, wystarczy spojrzeć do art. 15 u.p.z.p. wskazującego w ust. 2 na jego elementy obligatoryjne, a w ust. 3 na te wynikające $z$ jego przypisanej do konkretnych terenów specyfiki. Decyzja administracyjna nie uwzględnia zatem m.in. wymagań wynikających z potrzeb kształtowania przestrzeni publicznych, np. zarezerwowania miejsca na ośrodki oświatowe i ochrony zdrowia, tereny zielone, lokalne centra handlowe itp., czy zasad modernizacji, rozbudowy i budowy systemów komunikacji i infrastruktury technicznej. Budowanie, przykładowo, osiedli mieszkaniowych na podstawie decyzji o warunkach zabudowy niewątpliwie wpływa na intensyfikację ruchu samochodowego, a zatem na system komunikacji, przede wszystkim na natężenie ruchu zarówno samochodowego, jak i rowerowego czy pieszego. Jednak analiza natężenia ruchu i jej skutków nie jest uwzględniona

${ }^{42}$ Wyrok WSA w Białymstoku z 13 III 2013 r., sygn. II SA/Bk 1016/12 (orzeczenie prawomocne), LEX nr 1302954.

${ }^{43}$ Wyrok WSA w Łodzi z 5 III 2013 r., sygn. II SA/Łd 1252/12 (orzeczenie prawomocne), LEX nr 1303662. 
w przesłankach wskazanych w art. 61 ust. 1 u.p.z.p. Co więcej, dominujący w doktrynie pogląd o związanym charakterze takiej decyzji nakazuje organowi wydać pozytywne rozstrzygnięcie, a znowelizowany art. 56 u.p.z.p. ${ }^{44}$ nie pozwala na odwołanie się do wykładni funkcjonalnej czy celowościowej ustawy. Zauważyć należy, że to w miejscowym planie, ewentualnie $\mathrm{w}$ decyzji lokalizacyjnej, można przeznaczyć określone tereny pod drogi publiczne, lub też nakazać poszerzenie istniejących, w tym budowę ścieżek rowerowych ${ }^{45}$. Nie ma bowiem wątpliwości, że co do zasady to miejscowy plan może zmienić przeznaczenie terenu i w konsekwencji doprowadzić do wywłaszczenia, jeśli będą realizowane cele publiczne, do których należy m.in. budowa dróg publicznych czy systemów komunikacji.

Dodatkowo zagospodarowanie dużej działki gruntu na podstawie aktu indywidualnego, o czym wspomniano wcześniej, pozbawia społeczność lokalną etapu konsultacji społecznych, obowiązkowych przy uchwalaniu m.p.z.p. Możliwość składania wniosków i uwag zakłada potencjalny wpływ na ostateczny kształt miejscowego planu. Natomiast przy postępowaniu administracyjnym prowadzonym zgodnie z k.p.a. w praktyce to organ decyduje o tym, kto jest stroną postępowania, i często ogranicza się do włączenia w toczące się postępowanie tylko właścicieli działek bezpośrednio sąsiadujących z tą objętą wnioskiem. Tym samym inni potencjalnie zainteresowani rozstrzygnięciem często nie mają nawet informacji o wniosku w sprawie ustalenia lub zmiany sposobu zagospodarowania i zabudowy nieodległych terenów.

O tym, że w planowaniu przestrzennym coraz większy nacisk kładziony jest na zakres partycypacji społecznej, ważenie interesów publicznego i indywidualnego, w tym ochronę istniejącego stanu zagospodarowania terenu, a także transportochłonność układu przestrzennego, świadczą najnowsze zmiany $\mathrm{w}$ art. 1 u.p.z.p. dokonane przy okazji uchwalenia Ustawy z dnia 9 października 2015 r. o rewitalizacji ${ }^{46}$. Nowe dyrektywy określone w ust. 4 art. 1 u.p.z.p. w sprawie sytuowania nowej zabudowy nakazują w sposób bardziej kompleksowy traktować przestrzeń i kładą nacisk na efektywność gospodarowania oraz walory

${ }^{44}$ Art. 56 zd. 2 u.p.z.p. stanowi, że „Przepis art. 1 ust. 2 (u.p.z.p) nie może stanowić wyłącznej podstawy odmowy ustalenia lokalizacji inwestycji celu publicznego".

${ }^{45}$ Wyjątkowo wydzielenie gruntów pod drogi publiczne następuje poprzez podział czy też scalenie i podział nieruchomości, a więc instytucje z ustawy o gospodarce nieruchomościami, a także na podstawie ustaw szczególnych, np. tzw. „specustawy” drogowej.

${ }^{46}$ Dz.U. poz. 1777 ze zm. 
ekonomiczne, które przejawiają się m.in. w maksymalnym wykorzystaniu publicznego transportu zbiorowego jako podstawowego środka transportu czy zapewnieniu rozwiązań przestrzennych ułatwiających przemieszczanie się pieszych i rowerzystów. Powyższe ma zapobiegać dalszemu niekontrolowanemu rozpraszaniu zabudowy miejskiej i przeciwdziałać dominacji transportu indywidualnego. W świetle powyższego lokalizowanie na podstawie decyzji o warunkach zabudowy wielu obiektów budowlanych na rozległym obszarze bez uwzględnienia przedstawionych wytycznych, w tym transportochłonności, jest działaniem wbrew intencjom ustawodawcy. Przy tym, mimo wprowadzonych zmian, przesłanki wydania tej decyzji określone w art. 61 u.p.z.p. pozostały takie same, stąd niemożliwe jest uwzględnienie niektórych nowych dyrektyw przy jej wydawaniu. Tym samym osiagnięcie założonych celów możliwe będzie przede wszystkim poprzez uchwalanie miejscowych planów, co przemawia za tym, by decyzja o warunkach zabudowy nie dokonywała znaczacych zmian w zagospodarowaniu przestrzeni, a decydowanie o istotnych zmianach w zabudowie dokonywało się na podstawie aktu normatywnego, a nie administracyjnego.

Ponadto do interesujących wniosków doprowadzają refleksje nad stosowaniem zasady "dobrego sąsiedztwa”. Zgodnie z nią, jeśli co najmniej jedna działka sąsiednia jest zabudowana w sposób pozwalający na określenie wymagań dotyczących nowej zabudowy w zakresie wskazanym w art. 61 ust. 1 u.p.z.p., to stanowić to może punkt odniesienia do zabudowy np. hektarowej działki. Wykładnia językowa doprowadza zatem do wniosku, że jeden obiekt budowlany stanowić może wytyczną planistyczną nawet dla kilkudziesięciu innych. W takim wypadku proporcje związane z powstaniem nowej zabudowy są z pewnością zachwiane. Reguła, że zasada "dobrego sąsiedztwa" pozwalałaby wybudować tylko jeden obiekt budowlany, gwarantowałaby brak możliwości dokonania istotnej ingerencji w istniejący układ zabudowy. Natomiast, zdaniem autora, zabudowa większą liczbą obiektów budowlanych to już tworzenie nowego ładu przestrzennego, kiedy zaś dzieje się to na postawie decyzji o warunkach zabudowy, to tym samym nie są spełniane wymogi wskazane w art. 15 u.p.z.p. Rodzi się zatem zasadnicze pytanie, czy ustawodawca dopuszcza powstawanie ładu przestrzennego dwóch jakości. Pierwszy byłby pełnym, kształtowanym przez miejscowy plan, uwzględniający pewne obszary jako jednorodne i spójne, drugi natomiast punktowym, powstającym na podstawie decyzji o warunkach zabudowy. 


\section{Podsumowanie}

W orzecznictwie podnosi się, że na gruncie planowania przestrzennego konieczne jest takie wyważenie interesów, aby w jak największym stopniu zabezpieczyć i rozwiązać potrzeby wspólnoty, a przy tym w jak najmniejszym naruszyć prawa właścicieli nieruchomości objętych planem ${ }^{47}$. Jednak interesy wspólnoty nie mogą być wyrażane wyłącznie poprzez realizację inwestycji celu publicznego, ale również poprzez wprowadzanie racjonalnego układu przestrzennego zachęcającego do pozostawania w nim. Wartości te są przecież zauważane przez ustawodawcę, który nakazuje przy sporządzaniu studium wiążącego organy gminy przy tworzeniu miejscowych planów uwzględniać jakość życia mieszkańców. Mimo że komfort zamieszkiwania członków wspólnoty lokalnej jest jednym z wielu czynników uwzględnianych przy sporządzaniu planów, to nie można a priori założyć, że jako z istoty swej ocenny, może być dowolnie kształtowany.

Nadto zauważa się, że nieuchwalenie miejscowego planu oznacza, iż gmina niejako zrzeka się kompetencji do samodzielnego decydowania o lokalnym porządku planistycznym na rzecz prima facie związanej decyzji administracyjnej ${ }^{48}$, której to wydanie reguluje przede wszystkim art. 61 u.p.z.p. Konsekwencje takiego legalnego zaniechania są daleko idące, gdyż ustawa o planowaniu i zagospodarowaniu przestrzennym nie wprowadza wymogu zgodności decyzji o warunkach zabudowy ze studium kierunków i uwarunkowań zagospodarowania przestrzennego gminy, jak czyni to w przypadku miejscowego planu. Co prawda, zdaniem Z. Niewiadomskiego, nie oznacza to, że taki akt indywidualny może być niezgodny ze studium ${ }^{49}$, chociażby poprzez odwołanie się do art. 1 ust. 2 u.p.z.p., to jednak brak formalnego związania powoduje, iż pogląd ten nie jest powszechnie akceptowany. Zdaniem autora jest to słuszny kierunek analizy pozycji prawnej decyzji o warunkach zabudowy, co potwierdza choćby najnowsze orzecznictwo $\mathrm{NSA}^{50}$, jednak praktyka działania organów gminy wielokrotnie daje przykłady ich wzajemnej niezgodności, czy wręcz sprzeczności.

${ }^{47}$ Wyrok NSA z 4 IV 2012 r., sygn. II OSK 232/12, LEX nr 1251928.

${ }^{48}$ Zob. Z. Leoński, M. Szewczyk, M. Kruś, op. cit., s. 198.

${ }^{49}$ Planowanie i zagospodarowanie przestrzenne. Komentarz, pod red.Z. Niewiadomskiego, Warszawa 2009.

${ }^{50}$ W wyroku z 6 VII 2009 r. (sygn. II OSK 1250/08, LEX nr 552846) NSA uznał, że ustawowe zastrzeżenie braku waloru aktu prawa miejscowego studium nie oznacza, iż decyzje administracyjne w przedmiocie warunków zabudowy wydawane dla terenów objętych studium mogą być sprzeczne z jego ustaleniami. 
Przekazanie gminie jako zdecentralizowanej jednostce samorządu terytorialnego władztwa planistycznego niewątpliwie jest słusznym rozwiązaniem. Wiążący się z nim zakres dyskrecjonalności z jednej strony jest pożądany, gdyż pewien obszar "twórczego luzu” wydaje się niezbędny przy planowaniu przestrzeni, z drugiej strony nie oznacza jednak dowolności. Tym samym wydawanie decyzji o warunkach zabudowy w odniesieniu do działki gruntu, na której ma zostać zlokalizowanych wiele obiektów budowlanych, nie jest właściwym odczytywaniem zawartej w ustawie aksjologii. Decyzja o warunkach zabudowy powinna dotyczyć pojedynczego zamierzenia budowlanego, natomiast planowanie wielu obiektów budowlanych powinno być możliwe wyłącznie na podstawie miejscowych planów. Tym bardziej nie powinno się na jej podstawie sytuować dominant planistycznych. Autor ma przy tym świadomość, że powyższe stanowisko wprowadzałoby nową kategorię obligatoryjnych miejscowych planów, ale zalety takiego sposobu kształtowania przestrzeni są jednoznacznie pozytywne, gdyż pozwala on na eliminację części zagrożeń związanych z wydawaniem decyzji o warunkach zabudowy dla działek gruntu o znacznej powierzchni.

Reasumując, miejscowy plan co do zasady nie powinien być uchwalany dla pojedynczej działki, jednego obiektu budowlanego, choć nie można przekreślać takiej możliwości, gdyż wyjątkowo może być to uzasadnione stanem faktycznym. Chociaż dyskusyjne jest stanowisko, że miejscowy plan jest niejako zbiorem aktów indywidualnych ustalających warunki zabudowy konkretnych nieruchomości ${ }^{51}$, to jednak oddaje ono po trosze jego istotę. Podkreślić przy tym należy, że dla kreowania ładu przestrzennego właściwym narzędziem jest akt generalny, zaś gwarancji takiej nie dają decyzje administracyjne o warunkach zabudowy.

\section{LEGAL DETERMINANTS OF ESTABLISHING THE SIZE OF THE AREA THAT IS SUBJECT TO THE DECISION REGARDING ITS DEVELOPMENT AND THE PROVISIONS OF LOCAL SPATIAL DEVELOPMENT PLANS}

\section{Su m mary}

This article deals with the issues that accompany areas that may become subject to a decision determining the conditions of their development and the provisions of the local spatial development plan. It was inspired by the land development plans

${ }^{51}$ Planowanie i zagospodarowanie przestrzenne. Komentarz, pod red. Z. Niewiadomskiego, Warszawa 2011, s. 147. 
drafted for the city of Poznan. The author wondered whether the area in question could, alternately, be regulated by a normative or administrative act. In other words, the question which was asked was whether there existed any legal determinants that could direct an application of a particular form of development. The research undertaken in this respect allowed to draw a conclusion that the currently binding Act on Planning and Spatial Development regulates only indirectly the matters raised. And yet, for reasons of functionality, extensive areas on which many constructions are planned to be erected, ought to be located on the basis of local plans. Only such plans account for (apart from determining the technical parameters of the planned structures) values such as public transport and its efficiency, technical infrastructure, local shopping centres and the like. Owing to them, a sustained development of these areas as well as spatial order can be ensured. Further, in an ideal model, decisions regarding the development conditions ought to be issued for individual building separately, and for relatively small areas. In the event of a large area it may be possible to secure its development in a manner significantly different from the existing structures. What it also means is that the new structures may be added to areas already developed, without the possibility of the local community to intervene. The possibility of an instrumental treatment of the development and land planning decisions is strengthened by the fact that formally it is not tied or related to any of the provisions of the investment plans of feasibility studies performed locally.

Keywords: local development plan - development conditions decision - analysed area 